\title{
BIOACTIVE COMPOUNDS AND SOME VITAMINS FROM VARIETIES OF PEPPER (CAPSICUM) GROWN IN CÔTE D'IVOIRE
}

\author{
Clément Kouassi Kouassi, ${ }^{\text {ab }}$ Zinzendorf Yéssé Nanga ${ }^{\text {bc }}$, Serge Joseph Lathro, ${ }^{\text {bc }}$ Solange Aka ${ }^{\text {ab }}$, Rose Koffi-Nevry, ${ }^{\text {a }}$ \\ ${ }^{a}$ Laboratoire de Biotechnologie et Microbiologie des Aliments de l'UFR des Sciences et Technologies des Aliments de l'Université d'Abobo- \\ Adjamé, 02 BP 801 Abidjan 02, Côte d'Ivoire. \\ ${ }^{\mathrm{b}}$ Laboratoire National de la Santé Publique, 18 BP 2403 Abidjan 18, Côte d'Ivoire. \\ ' Faculté des Sciences Pharmaceutiques et Biologiques, Université d'Abidjan-Cocody, BP V 34 Abidjan, Côte d'Ivoire. \\ *Corresponding author: kouacle@ yahoo.fr / clemankoici@ yahoo.fr Telephone: (225) 0848 63 76; Fax: (225) 21350873
}

\begin{abstract}
The aim of this work was to isolate groups of bioactive compounds of biological interest from some varieties of pepper (Capsicum) grown and consumed in Côte d'Ivoire, to assess the ability of organic solvent to extract these compounds and to determine ascorbic acid and beta-carotene content. Polar, non polar and acid compounds of intermediate polarity obtained by thin layer chromatography (TLC) were used to isolate from the acetone extracts, from 33 to 34 compounds for $C$. annuum and from 27 to 33 for $C$. frutescens. The number of lipid compounds isolated from C. аппиит varies from 32 to 33 and 24 to 29 in C. frutescens. The total non-lipid compounds obtained by the dichloromethane, acetone and methanol extract ranges from 88 to 103 for $C$. аnпиит, and from 84 to 96 for $C$. frutescens. The number of lipid compounds was higher for $C$. annuum than for $C$. frutescens. The lipid compounds and non-lipid compounds were highly variable depending on the variety of Capsicum. The ascorbic acid and beta carotene contents were obtained by High-performance liquid chromatography (HPLC). Beta-carotene content in pepper studied ranged from 68 to $535 \mu \mathrm{g} 100 \mathrm{~g} \mathrm{~g}^{-1} \mathrm{FW}$ and ascorbic acid from 86 to $96 \mathrm{mg} 100 \mathrm{~g} \mathrm{~g}^{-1} \mathrm{FW}$. The current study may contribute to the knowledge of the nutritional and the bioactive compounds of the fruit and may offer knowledge of the potential health benefits for bell pepper consumers in Côte d'Ivoire..
\end{abstract}

Keywords: Ascorbic Acid; Bioactive compounds; Beta carotene; Capsicum.

\section{Introduction}

The challenge of food security, the constant increase of microbial infections, and diseases related to malnutrition encourage the scientists to investigate new bioactive molecules. These molecules are secondary metabolites such as phenolic compounds, terpenoids, steroids and alkaloids [1, 2]. Fruit and vegetable are important source of bioactive compounds and antioxidant. Fruit, which are rich in antioxidant molecule, are known for their healthpromoting effect against degenerative diseases $[3,4$, 5]. Bell pepper (Capsicum) fruit varieties have been identified as potential vegetables with high antioxidant activity $[2,6]$.

The cultivation of Capsicum (Solanaceae) originated in Central and South America, with the species $C$. annuum, $C$. frutescens, $C$. baccatum, $C$. pubescens and $C$. chinense [2]. Pepper (Capsicum) is a tropical and an important agricultural crop and one of popular vegetables, not only because of its economic importance, but also for the combination of color, taste, pungency, flavor, aroma and nutritional value of its fruit [7, 8]. The genus Capsicum comprises more than 200 varieties, and the fruit vary widely in size, shape, flavor and sensory heat. Pepper fruit can be consumed at different ripening stages (green, red or not fully-ripe). Capsicum annиum and
C. frutescens are well known in Côte d'Ivoire for their flavour and burning sensation on the mouth [8]. The group of pungent components peculiar to the fruits of Capsicum plants is called capsaicinoids. It has been reported in recent studies that each capsaicinoid analogue is responsible for different burning sensation in the mouth [9]. They are commonly used as a spice or food and also for a broad variety of therapeutic applications.

Capsicum annuum is used in the form of fresh and processed colorants, such as paste, paprika and oleoresin. Their popularity stems from the combination of color, taste and pungency [7]. The dried or fresh form is used in many types of flavorings and cuisines for seasoning sauces. Bell pepper is usually consumed after being cooked in a sauce, cut into pieces in marinade or raw, for consumption in braise, roast, fry or cured meat or fish to accompanied attiéké, a cassava based product from Côte d'Ivoire [8]. It is used as an exhauster of peppery taste especially in a dish called kédjénou, very appreciate in Côte d'Ivoire [8]. Household cooking can cause either decreases or increases in the content of capsaicinoids and phenolic compounds in peppers [10].

In addition to flavoring food, few authors reported an increase of ascorbic acid and carotenoids content of 
several types of peppers upon maturation and ripening.

The intense, characteristic and attractive red color of Capsicum fruits is principally due to the pigments of capsanthin and capsorubin which belong to carotenoids. Of these carotenoids, only beta carotene and beta cryptoxanthin have a vitamin A activity affected by absorption and conversion by oxygenase enzymes which cleave carotenoids to retinol [11]. Thus, they are represented as being retinol equivalent (RE). In the United State of America, vitamin A values now are expressed as retinol activity equivalents (RAE), rather than RE. These carotenoids function as antioxidant at low oxygen pressure and they may protect tissues against free radical damage and peroxidation [12]. Carotenoids also play an important role in human health for their antioxidant and free-radical scavenging effect; prevention of certain types of cancer, cardiovascular disease, eye disorders, skin degeneration and aging.

The most important vitamin in fruit and vegetables is vitamin C. $90 \%$ of the ascorbic acid in human diet was supplied by them. Ascorbic acid plays significant functions in the body that enhance its role in the health status of the human body [13]. It is a vitamin whose prescribed requirement across cultures is not uniform. For instance, the prescribed requirement of vitamin $\mathrm{C}$ in Great Britain is $30 \mathrm{mg} /$ day, while in the U.S.A., it is $60 \mathrm{mg} /$ day, and $100 \mathrm{mg} /$ day in Japan, 60 or $75 \mathrm{mg} /$ day is recommended by OMS [13].

Peppers from Capsicum species are widely consumed in Côte d'Ivoire, but there are few reports in the literature on its chemical composition and biological properties. To the best of our Knowledge, the nutritional and therapeutic properties of the peppers grown in Côte d'Ivoire are not known. Therefore, it seems relevant to known the type of healthpromoting compounds present in these raw materials and their concentration. The present study was conducted to determine bioactive compounds and antioxidant vitamins contents of the ripe fruit of Capsicum used in Côte d'Ivoire.

\section{Materials and Methods}

\section{Plant Materials}

The study was carried out on commercial pepper samples from fresh whole fruit of five varieties, Capsicum annuum var. antillais, Capsicum annuum var. jaune, Capsicum frutescens var. doux, Capsicum frutescens var. soudanais and Capsicum frutescens var. attié at maturity stage of full fruit size. Plant materials were obtained from four local wholesale markets (Abobo, Adjamé, Treichville and Koumassi) in Abidjan, Côte d'Ivoire.

These fruits were surveyed and selected to compile a representative list of these Bell pepper fruits mostly used by traditional healers of Côte d'Ivoire for their availability, accessibility and wide utilization in food. These two Capsicum fruit varieties were identified by the Agency ANADER (National Agency for Rural Development) and confirmed by the national floristic center of the University of Cocody, Abidjan, Côte d'Ivoire. Capsicum annuиm selected were fresh, ripened and firm. Capsicum frutescens selected were dried because used in this state.

\section{Plant extracts preparation}

This method is adapted from [14] Fresh, unblemished fruits were washed then oven dried separately for 5 days for less fleshy fruit such as $C$. frutescens, and 8 to 10 days for fleshy fruits as $C$. annuиm. The dried fruit were spread out in an electric blender (Warring Commercial 8010E Model 38BL40, France) at $3000 \mathrm{rpm} \mathrm{min}{ }^{-1}$. The mixture obtained was sieved (with a mesh about 1-2 $\mathrm{mm}$ in diameter).

\section{Successive fruits extracts preparations}

The assay was used according to [14, 15] method. The following solvents were selected according to their degree of polarity (less polar to more polar): petroleum ether (VWR Prolabo, Normapur, CE-EMB 45,053), dichloromethane, acetone (Merck, Germany) and finally methanol (VWR Prolabo, Normapur, CE-EMB 45,053. Five gram $(5 \mathrm{~g})$ of powder for each variety of Capsicum was submitted to successive extractions using petroleum ether, dichloromethane, acetone and methanol until complete exhaustion, in order to obtain the petroleum ether, dichloromethane, acetone and methanol extracts, respectively. For the same solvent, the process of extraction was repeated six times with the same residue but using fresh solvent. The organic solvents were evaporated under reduced pressure to dryness to obtain the respective residues from fruit named $\mathrm{CPE}$ (crude petroleum ether extract), DCM (dichloromethane extract), ACT (acetone extract) and MET (methanol extract). Dry matter obtained with each solvent was measured and expressed as percent dry matter.

\section{Phytochemical screening}

Chemical component identification was done using TLC (thin layer chromatography) method in accordance to the methods described by $[14,16]$. The extracts obtained from the successive extraction were used for the phytochemical screening.

The presence of alkaloids, flavonoids, sapronosids, quinones, tannins, steroids, phenol and terpenes were determined using aluminium backed thin layer chromatography plates (cellulose plate for flavonoids, polyphenols, tannins and silica plate for sterols, terpenes, quinones, alkaloids and sapronosids) (GF 25460 Merck). In each case 50 $\mu \mathrm{g}$ 
was chromatographed. The following three solvent systems were used to develop the plates: System I: Acetic acid/ water (90:10) was used for flavonoids, tannins and phenols; System II: Chloroform/ methanol (98:2) for quinones, steroids and terpenes; System III: Chloroform/ methanol/water (65:25:10) for alkaloids. After drying the plates, the components were visualized under visible light (254 and $366 \mathrm{~nm}$ ) and sprayed with the following reagents in order to reveal spots of different groups: the sulphuric alcohol used for sterols and terpenes, solution of Draggendorff reagent for alkaloids, alcoholic potash with $5 \%$ is used for quinines, ferric chloride with $3 \%$ is used for tannins, reagent of Godin and the sulphuric acid are used for the sapronosids. Greenish yellow indicates the presence of flavonoids and polyphenols, alkaloids was revealed by an orange color, sterols and terpenes by a brown color, saponins by violet and blue color after heating, tannins by a blue, green and black color and the presence of quinones by red spots. The experiment was conducted in triplicate.

\section{L-beta carotene determination}

The beta carotene from the sample was extracted according to the method described by [11, 17]. $20 \mathrm{~mL}$ of $99.8 \%$ ethanol and $5 \mathrm{ml}$ of $100 \%$ (w/v) potassium hydroxide were homogenised for 5 min using a blender, then added in $5 \mathrm{~g}$ of each variety of pepper fruits. The mixture was saponified, heated for $30 \mathrm{~min}$, and then cooled to room temperature. The mixture was frequently agitated to avoid any aggregation. The extraction was performed with nhexane. All samples were carried out in triplicates. Quantification of $\beta$-carotene was made by external standard of $\beta$-carotene (Sigma, Co. Chemical, St. Louis, USA) dissolved in pure $\mathrm{n}$-hexane at final concentration of $1 \mu \mathrm{g} / \mathrm{mL}$.

\section{L- ascorbic acid determination}

Ascorbic acid was quantitatively extracted by using a relatively simple and fast citric acid method as described by [18, 19] with. Fresh samples $(5 \mathrm{~g})$ from each variety of pepper fruits were homogenised with $5 \mathrm{~mL}$ of $3 \%$ (w/v) citric acid (Merck). The extract was mixed and centrifuged at $3000 \mathrm{~g}$ for $15 \mathrm{~min}$ at $5^{\circ} \mathrm{C}$.

The slurry was filtered through Whatman paper $\mathrm{n}^{\circ} 4$ and then, using $0.45 \mathrm{~mm}$ membrane filter (Millipore) (Sartorius AG, Gottingen, Germany) and stored at $-20{ }^{\circ} \mathrm{C}$ until used for HPLC injections. Quantification of ascorbic acid was made by external standard of ascorbic acid (Sigma, Co. Chemical, St. Louis, USA) dissolved in the mobile phase (3\% $(\mathrm{w} / \mathrm{v})$ citric acid (Merck) at final concentration of 1 $\mathrm{mg} / \mathrm{mL})$.

\section{High-performance liquid chromatography analysis conditions}

Separation and quantification of beta carotene and ascorbic acid was carried out using an ion exclusion ORH-801 column (300 x $6.5 \mathrm{~mm})$ (Interchrom, France) preceded by an Universal Gard Cartritge-Holder column. The High Liquid Chromatography system (LC-6A, Schimadzu corporation, Japan) was equipped with, Schimadzu LC-6A pump column effluent monitored by an UV detector (SPD-6A Schimadzu corporation, Japan) at $250 \mathrm{~nm}$ and $450 \mathrm{~nm}$ for vitamin $\mathrm{C}$ and $\beta$-carotene respectively.

The flow rate for $\beta$-carotene was 1.7 $\mathrm{mL} / \mathrm{min}$, and the sample injection volume was $20 \mu \mathrm{l}$. That of vitamin $\mathrm{C}$ was $1.5 \mathrm{~mL} / \mathrm{min}$ and the sample injection volume was $20 \mu \mathrm{l}$. The eluent was for vitamin $\mathrm{C}$ and $\beta$-carotene was water at $\mathrm{pH} 2.3$ acetone-water (75:25) respectively, were filtered through a $0.45 \mu \mathrm{m}$ Millipore membrane filter (Sartorius AG, Goëttingen, Germany). Each sample was injected in duplicate. The standard vitamins were filtered and injected as the samples. Ascorbic acid or beta carotene in sample was identified by comparing their retention times with those of standard Lascorbic acid or standard $\beta$-carotene. Vitamin quantification was calculated from the curve generated by plotting the peak area of each authentic standard versus concentrations. A $20 \mu$ injection volume was used for HPLC samples. The analyses were done in triplicate and mean values calculated.

\section{Statistical analysis}

The results were statistically evaluated by one way analysis of variance (ANOVA) with the software Statistica, 99 Edition. Statistical differences with P-values under 0.05 were considered significant. Results

\section{Bioactive compounds in Capsicum varieties}

The samples investigated were analyzed for total bioactive compounds (Table 1). All the varieties of Capsicum studied contain metabolites such as steroids, terpenes, flavonoids, polyphenols and quinone. The methanol extracts differ from the others by the presence of tannins. The number of bioactive compounds determined according to the different (3) solvent systems was shown in table 2. Polar, non polar and intermediate polarity compounds were counted in the crude acetone extracts and the organic extracts. The higher number of polar compounds was obtained with the DCM extract in $C$. annuum jaune (17). Therefore DCM extract is the solvent that extracts the largest numbers of compounds and CEP, the lowest number in $C$. frutescens attie (04). The DCM extract presented the highest total number of compounds (146) among all the samples tested, and 
Table 1. Bioactive metabolites from Capsicum varieties identified by high-performance liquid chromatography

\begin{tabular}{|c|c|c|c|c|c|c|c|c|c|}
\hline \multirow{2}{*}{$\begin{array}{l}\text { Pepper } \\
\text { varieties }\end{array}$} & \multirow[t]{2}{*}{ Solvents } & \multicolumn{6}{|c|}{ bioactive compound } & \multirow[b]{2}{*}{ Flavonoïdes } & \multirow[b]{2}{*}{ Polyphénols } \\
\hline & & Alcaloïdes & Saponosides & Quinones & Tannins & Stéroïdes & Terpènes & & \\
\hline \multirow{4}{*}{$\begin{array}{l}\text { C. annuum } \\
\text { antillais }\end{array}$} & E. Pétrole & + & - & + & - & + & + & + & + \\
\hline & Dichloromethane & + & - & + & - & + & + & + & + \\
\hline & Acetone & + & - & + & - & + & + & + & + \\
\hline & Methanol & + & - & + & + & + & + & + & + \\
\hline \multirow{4}{*}{$\begin{array}{l}\text { C. annuum } \\
\text { jaune }\end{array}$} & E. Pétrole & + & - & + & - & + & + & + & + \\
\hline & Dichlorométhane & + & - & + & - & + & + & + & + \\
\hline & Acétone & + & - & + & - & + & + & + & + \\
\hline & Méthanol & + & - & + & + & + & + & + & + \\
\hline \multirow{4}{*}{$\begin{array}{c}C . \\
\text { frutescens } \\
\text { soudanais }\end{array}$} & E. Pétrole & + & - & + & - & + & + & + & + \\
\hline & Dichlorométhane & + & - & + & - & + & + & + & + \\
\hline & Acétone & + & - & + & - & + & + & + & + \\
\hline & Méthanol & + & - & + & + & + & + & + & + \\
\hline \multirow{4}{*}{$\begin{array}{c}C . \\
\text { frutescens } \\
\text { attié }\end{array}$} & E. Pétrole & + & - & + & - & + & + & + & + \\
\hline & Dichlorométhane & + & - & + & - & + & + & + & + \\
\hline & Acétone & + & - & + & - & + & + & + & + \\
\hline & Méthanol & + & - & + & + & + & + & + & + \\
\hline \multirow{4}{*}{$\begin{array}{c}C . \\
\text { frutescens } \\
\text { doux }\end{array}$} & E. Pétrole & + & - & + & - & + & + & + & + \\
\hline & Dichlorométhane & + & - & + & - & + & + & + & + \\
\hline & Acétone & + & - & + & - & + & + & + & + \\
\hline & Méthanol & + & - & + & + & + & + & + & + \\
\hline
\end{tabular}

+: presence of the title compound; - : absence of the title compound.

Table 2. Total number of bioactive compounds obtained from the Capsicum varieties tested according to the different extraction systems

\begin{tabular}{|c|c|c|c|c|c|c|}
\hline & & CAJ & CAA & CFA & CFD & CFS \\
\hline \multirow{4}{*}{ System I } & CPE & 11 & 11 & 4 & 5 & 10 \\
\hline & DCM & 11 & 15 & 10 & 9 & 10 \\
\hline & ACT & 8 & 11 & 11 & 10 & 9 \\
\hline & MET & 9 & 10 & 9 & 10 & 9 \\
\hline \multirow{4}{*}{ System II } & CPE & 11 & 10 & 13 & 8 & 6 \\
\hline & DCM & 14 & 14 & 15 & 13 & 13 \\
\hline & ACT & 15 & 8 & 10 & 7 & 5 \\
\hline & MET & 10 & 9 & 12 & 14 & 9 \\
\hline \multirow{4}{*}{ System III } & CPE & 13 & 11 & 12 & 11 & 10 \\
\hline & DCM & 17 & 9 & 12 & 13 & 10 \\
\hline & ACT & 12 & 7 & 9 & 11 & 9 \\
\hline & MET & 7 & 5 & 8 & 10 & 8 \\
\hline
\end{tabular}


the MET extract presented the lowest (139). Regarding the total flavonoid content (Table 1), the highest amount was found in the dichloromethane extract of the fruit. In general, all the systems of chromatographic development have highlighted the many bioactive compounds. The higher number of compounds was revealed by extraction systems II, followed by extraction system III and system I gave the lowest number of compounds.

Beta carotene and ascorbic acid content in Capsicum varieties

Beta carotene (pro vitamin A) and ascorbic acid (vitamin C) contents of the three bell pepper varieties were shown in table 3 . Beta carotene content in pepper studied ranged from 68.47 to $535.98 \mu \mathrm{g}$ $100 \mathrm{~g}^{-1}$ and ascorbic acid from 86.38 to $96.62 \mathrm{mg} 100$ $\mathrm{g}^{-1}$. Capsicum annum antillais has the highest level of ascorbic acid (96.62 $\mathrm{mg} 100 \mathrm{~g}^{-1}$ ) and $\beta$-carotene content $\left(535.98 \mu \mathrm{g} 100 \mathrm{~g}^{-1}\right)$ followed by $C$. frutescens doux, 87.95 and $434.45 \mu \mathrm{g} 100 \mathrm{~g}^{-1}$ respectively. The lowest level of $\beta$-carotene was observed with $C$. annuum jaune $\left(68.47 \mu \mathrm{g} 100 \mathrm{~g}^{-1}\right)$. Capsicum annuum cultivar antillais has the highest $\beta$-carotene content $\left(535.98 \mu \mathrm{g} 100 \mathrm{~g}^{-1}\right)$, followed by $C$. frutescens doux (434.45 $\left.\mu \mathrm{g} 100 \mathrm{~g}^{-1}\right)$. There were significant differences $(\mathrm{P}<0.05)$ between $\beta$-carotene content among the three Capsicum cultivars examined in this work. There was a significant difference $(\mathrm{P}<0.05)$ between ascorbic acid content of $C$. annuum antillais $\left(96.62 \pm 19.42 \mathrm{mg} 100 \mathrm{~g}^{-1}\right)$ and the other two varieties studies. However, no significant difference $(\mathrm{P}>0.05)$ was noted for ascorbic acid content between $C$. annuum jaune and $C$. frutescens doux.

\section{Discussion}

The ability of methanol to extract tannins was observed by other authors [20, 21]. According to Dharmananda [22], tannins are responsible for the astringent taste of vegetables. The presence of tannins in Capsicum peppers support the traditional medicinal use of these fruits in treatment of different illnesses. They are used to treat intestinal disorders such as diarrhea and dysentery and have antimicrobial activity. $\mathrm{Li}$ et al. [3] reviewed the biological activity of tannins and they observed that they have remarquable activity in cancer prevention and as anticancer agents, thus suggesting that Capsicum fruits have potentials as source of important bioactive molecules for treatment and prevention of cancer.

One of the most common biological properties of alkaloids is their toxicity against the cells of living organisms. In addition, the alkaloids have anti-inflammatory, asthma, anaphylactic properties by modifying the immune status in vivo. The alkaloids are used in painkillers [23]. Some alkaloids are very active on chloroquine-resistant plasmodium [24]. Flavonoids have a wide range of biological activities (antimicrobial, antileishmanial and antitrypanosomal, anti-inflammatory antiangioniques, analgesic, antiallergic, antioxidant and cytostatic) [25].

For Ferguson [26], flavonoids promote health by preventing diseases associated with oxidative damage of membrane, protein and DNA. Flavonoids in the human diet reduce the risk of various cancers and prevent menopausal symptoms. Epidemiological studies suggest that the consumption of flavonoids is effective in lowering the risk of coronary heart disease. Furthermore, several flavonoids exhibit antiviral activities [27]. The presence of sterol, polyphenols, terpenes and quinones has earlier been reported with antimicrobial activity [28]. Quinones are popular for its antiamoebal activity against the malaria parasite. The presence of these components makes the Capsicum fruit food with high bioactive potential. Howether, the material extracted vary according to the variety of pepper, the nature and the physicochemical characteristics of the solvents used, including their polarity. These results were in agreement with those of $[1,2,29]$ who indicated that $C$. annuum and $C$. frutescens have a wide array of phytochemicals with well-known antioxidant properties.

Beta carotene content in $C$. annuum and $C$. frutescens varieties have been extensively studied and characterized for selecting high-carotenoid producing cultivars [30]. The beta carotene content of $C$. annuum jaune was lower than those of the other two varieties studied (Table 3). Marin et al. [31] reported a high pro-vitamin A content in the mature stage of peppers. Recently, Guzman et al. [11] indicated that orange or yellow color in Capsicum fruit can have very low amounts of the $\beta$-carotene level. The level of $\beta$-carotene in pepper depends upon various factors: the level of expression of the genes governing carotenogenesis, physiological and morphological characteristics intrinsic to the cultivar, and probably growth conditions [31].

Beta carotene content reported in this work falls within the range reported by other authors for pepper fruits [30, 32]. Ha et al. [32] observed that beta carotene content in the Capsicum cultivars ranged from 100 to $1300 \mu \mathrm{g} 100 \mathrm{~g}^{-1}$ fresh weight. Guzman et al. [11] indicated that $\beta$-carotene contents could range from $100 \mu \mathrm{g}$ to $6000 \mu \mathrm{g} 100 \mathrm{~g}^{-1}$ dry weigh. The more recently devised Dietary Reference Intake (DRI), [33] values for vitamin A, established by the Food and Nutrition board of the Institute of Medicine are, 900 and $700 \mu \mathrm{g}$ RAE/day for adult (ages 19-50 years) males and females, respectively 
(IOM) [33]. The RAE of the varieties cannot be calculated without their content beta cryptoxanthin or total pro vitamin A compounds. Based on these references, the consumption of about $100 \mathrm{~g}$ fresh bell pepper fruits in a day would provide between $30 \%$ and $60 \%$ of US DRI values of vitamin A for an adult, depending on the Capsicum variety and ripeness.

Vitamin $\mathrm{C}$ content in the peppers ranged from 86 to $96 \mathrm{mg} 100 \mathrm{~g}^{-1}$. Higher ascorbic acid content was determined in $C$. апnиum antillais (Table 3 ). This result was similar to those of Frary et al. [34] who found vitamin C content from 52 to $163 \mathrm{mg} 100$ $\mathrm{g}^{-1}$ in Capsicum cultivars investigated, and also in accordance with those seen in other studies $[19,31$, 34].

However results in this work disagree with those reported by Cruz-Perez et al. [7] which indicated lower levels of ascorbic acid contents, between 5 and $63 \mathrm{mg} 100 \mathrm{~g}^{-1}$ fresh weights of five ripe Capsicum fruits. A notable exception is the work of Guil-Guerrero et al. [35] which reported high

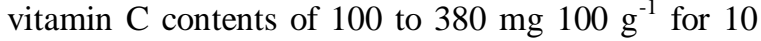
Capsicum cultivars grown in Spain.

Kumar and Tata [36] showed considerable variation in ascorbic acid content ranging from $44 \mathrm{mg}$

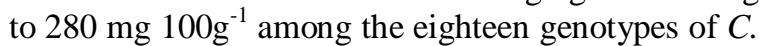
aпnиит studied and concluded higher ascorbic acid content in the ripening red stages rather than in the green stage. The lower values of ascorbic acid found in this study in comparison to other studies could be explained by the maturity stage. Harvested at the red stage contained significantly greater ascorbic acid levels $\left(153 \mathrm{mg} 100 \mathrm{~g}^{-1}\right)$ than green fruit. Variation in ascorbic acid content can be attributed to multiple factor such as temperature fluctuations, cultivar response and sampling variation. This difference could be explained by the fact that the fruits were probably not harvest at the same age, therefore of the same generation, maturation and not treated by the same commercial agricultural practices [7, 36]. Furthermore, minor differences in the extraction methods may be attributed to such differences in ascorbic acid results. Interestingly, the cultivars assayed in this work could supply $100 \%$ of the daily Recommended Dietary Allowance (RDA) of vitamin C. The devised Dietary Reference Intake (DRI) values for vitamin $C$ are 75 and $90 \mathrm{mg} /$ day for adult males and females, respectively [33]. Considering these values, consuming about $100 \mathrm{~g}$ fresh ripe fruits in a day would provide $114 \%$ to $128 \%$ of US DRI values of vitamin $\mathrm{C}$ for an adult (ages 19-50 years) male, and $95 \%$ to $106 \%$ for adult (ages $19-50$ years) female depending on the Capsicum variety.
Table 3. Beta carotene and ascorbic acid contents of the three pepper cultivars

\begin{tabular}{lcc}
\hline Varieties & $\begin{array}{c}\text { Beta carotene } \\
(\mu \mathrm{g} / 100 \mathrm{~g} \text { fresh } \\
\text { weight })\end{array}$ & $\begin{array}{c}\text { Ascorbic acid } \\
(\mathrm{mg} / 100 \mathrm{~g} \text { fresh } \\
\text { weight })\end{array}$ \\
\hline $\begin{array}{l}\text { Capsicum annuum } \\
\text { antillais }\end{array}$ & $535.98^{\mathrm{a}} \pm 185.56$ & $96.62^{\mathrm{b}} \pm 19.42$ \\
$\begin{array}{l}\text { Capsicum annuum } \\
\text { jaune }\end{array}$ & $68.47^{\mathrm{b}} \pm 27.48$ & $86.38^{\mathrm{a}} \pm 20.25$ \\
$\begin{array}{l}\text { Capsicum } \\
\text { frutescens doux }\end{array}$ & $434.45^{\mathrm{c}} \pm 176.69$ & $87.95^{\mathrm{a}} \pm 10.90$ \\
\hline $\begin{array}{l}\text { The values are mean } \pm \text { standard error }(\mathrm{n}=70) . \\
\text { significant at } \mathrm{P}<0.05 . \text { The significant, } *\end{array}$ \\
$\begin{array}{l}\text { different superscript letters are significantly }(\mathrm{P}<0.05) \text { different } \\
\text { (Dunan's Multiple Range Test). }\end{array}$
\end{tabular}

\section{Conclusion}

The polar, non-polar and the acidic compounds of intermediate polarity from crude acetone and petroleum ether extracts showed less variability regardless of the variety of Capsicum studied. C. annuиm antillais that had higher beta carotene content had also higher ascorbic acid content. It comes out from this study that $C$. аппиит and $C$. frutescens are a great source of potential bioactive compounds. The current findings are essential as new information to the scientific database in Côte d'Ivoire, due to a lack of related literature on the varieties of bell pepper fruit grown, consumed and used in traditional medicine. The current study may contribute to the knowledge of the nutritional and the bioactive compounds of the fruit and may offer knowledge of the potential health benefits for bell pepper consumers in Côte d'Ivoire.

\section{Acknowledgements}

The authors are thankful to the Food Science Department of Abobo-Adjamé University, for laboratory facilities; the National Laboratory of Public Health for providing chemical and technical material support to conduct the research.

\section{Reference}

1. Hervert-Hernandez D, Sayago-Ayerdi SG, Goni I (2010). Bioactive compounds of four hot pepper varieties (Capsicum annuиm L.): antioxidant capacity, and intestinal bioaccessibility. Journal of Agricultural and Food Chemistry, 58: 3399-3406

2. Zimmer AR, Leonardi B, Miron D, Schapoval E, Oliveira JR, Gosmann G (2012). Antioxidant and anti-inflammatory properties of Capsicum baccatum: From traditional use to scientific approach. Journal of Ethnopharmacology, 139 (1): 228-233

3. Li F, Awale S, Tezuka Y, Kadota S (2008). Cytotoxic constituents from Brazilian red propolis 
and their structure-activity relationship. Bioorganic \& Medicinal Chemistry, 16: 54345440

4. Meghvansi MK, Siddiqui S, Khan MH, Gupta VK, Vairale MG, Gogoi HK, Singh L (2010). Naga chilli: a potential source of capsaicinoids with broad-spectrum ethnopharmacological applications. Journal of Ethnopharmacology, 132: $1-14$

5. Koffi-Nevry R, Kouassi CK, Zinzerdorf YN, Koussémon M, Yao GL (2012). Antibacterial activity to two bell pepper extracts: Capsicum annuum $\mathrm{L}$ and Capsicum frutescens. International Journal of food Properties, (in press).

6. Mueller M, Hobiger S, Jungbauer A (2010). Antiinflammatory activity of extracts from fruits, herbs and spices. Food Chemistry, 122 : 987-996

7. Cruz-Perez AB, Gonzalez-Perez VA, Soto Hermandez RM, Gutierrez-Espinosa MA, GardeaBéjar AA, Perez-Grajalez M (2007). Capsainoid, vitamin $\mathrm{C}$ and heterosis during fruit development of Manzano hot pepper. Agrociena, 41: 627-635

8. Kouassi KC, Koffi-Nevry R (2012). Evaluation de la connaissance et utilisation des variétés de piment (Capsicum) cultivées en Côte d'Ivoire. International Journal of Biological and Chemical Sciences, 6 (1): 175-185

9. Kollmannsberger H, Rodriguez-Burruezo A, Nitz S, Nuez F (2011). Volatile and capsaicinoid composition of aji (Capsicum baccatum) and rocoto (Capsicum pubescens), two Andean species of chile peppers. Journal of the Science of Food and Agriculture, 91: 1598-1611

10. Ibarra-Junquera, Guadalupe I, Olivas J, PérezMartínez JD (2010). Effect of cooking on the capsaicinoids and phenolics contents of Mexican peppers. Food Chemistry, 119 (4): 1619-1625

11. Guzman I, Hamby S, Romero J, Bosland PW, O’Connell MA (2010). Variability of Carotenoid Biosynthesis in Orange Colored Capsicum spp. Plant Science, 179 (1-2): 49-59

12. Rodriguez-Burruezo A, Gonzalez-Mas Mdel C, Nuez F (2010). Carotenoid composition and vitamin A value in aji (Capsicum baccatum L.) and rocoto (C. pubescens R. \& P.), 2 pepper species from the Andean region. Journal of Food Science, 75: 446-453

13. Walingo K.M. (2005). Role of vitamin C (ascorbic acid) on human health-a review. African
Journal of food, Agriculture, Nutrition and Development, 5:1

14. Angeh JE (2006). Isolation and characterization of antibacterial compounds present in members of Combretum section, Hypocrateroppsis. $\mathrm{PhD}$ Thesis. University of Pretoria. Prétoria, Afrique du Sud. 210 pp.

15. Eloff JN (2004). Quantifying the bioactivity of plant extract during screening and bioassayguided fractionation. Phytomedicine, 11: 370-371

16. Békro YA, Békro MJ, Boua BB, Tra Bi FH, Ehile EE (2007). Etude ethnobotanique et screening phytochimique de Caesalpinia benthamiana (Baill.) Herend. Et Zarucchi (Caesalpiniaceae). Sciences et Nature, 4 : 217-225

17. Amin I, Cheah SF (2003). Determination of vitamin $\mathrm{C}, \beta$ carotene and riboflavin contents in five green vegetables organically and conventionally grown. Malaysian Journal of Nutrition 9 (1): 31-39

18. Albuquerque B, Lidon CF, Leitao EA (2005). Ascorbic acid quantification in melon samples: the importance of the extraction medium for HPLC analysis. General and Applied Plant Physiology, 31 (3-4): 247-251

19. Deepa N, Kaur C, Singh B, Kapoor HC (2006). Antioxidant activity in some red sweet pepper cultivars. Journal of Food Composition and Analysis, 19: 572-578

20. N'Guessan K, Kadja B, Zirihi GN, Traoré D, Aké-Assi L (2009). Screening phytochimique de quelques plantes médicinales ivoiriennes utilisées en pays Krobou (Agboville, Côte-d'Ivoire). Sciences \& Nature, 6 (1): 1-15

21. Kouassi CK, Koffi-Nevry R, Nanga ZY, Teixeira Da Silva JA, Yao K, Lathro JS, Tano K, Loukou GY (2010). Assessing the antibacterial activity and phytochemical screening of Capsicum varieties from Côte d'Ivoire. Food, 4 (1): 27-32

22. Dharmananda S (2003). Gallnuts and the uses of tannins in Chinese medicine. In: Proceedings of the Institute for Traditional Medicine, Portland, Oregon, pp 2.

23. Staerk D, Lykkeberg AK, Christensen J, Budnik BA, Abe F, Jaroszewki JW (2002). In vitro cytotoxic activity of phenanthroindolizidine alkaloids from Cynanchum vincetoxicum and Tylophora tanake against drug-sensitive and 
multidrug-resistant cancer cells. Journal of Natural Products, 65 (9): 1299-1302

24. Verpoorte R (2005). Alkaloids. Encyclopedia of Analytical Science 56 -61

25. Tasdemir D, Kaiser M, Brun R, Yardley V, Schmidt TJ, Tosun F, Reudi P (2006). Antitrypanosomal and antileishmanial activities of flavonoids and their analogues: In vitro, in vivo, structure-activity relationship, and quantitative structure-activity relationship studies. Antimicrobial Agents and Chemotherapy, 50 (4): 1352-1364

26. Ferguson LR (2001). Role of plant polyphenols in genomic stability. Mutation Research, 475: 89111

27. Xu HX, Wan M, Dong H, But PP, Foo LY (2000). Inhibitory activity of flavonoids and tannins against HIV-1 protease. Biological and Pharmaceutica Bulletin, 23: 1072-1076

28. Hassan SW, Umar RA, Lawal M, Bilbis LS, Muhammad BY, Dabai YU (2006). Evaluation of antibacterial activity and phytochemical analysis of root extracts of Boscia angustifolia. Journal of Biotechnology, 5 (18): 1602-1607

29. Pino J, Gonzalez M, Ceballos L, Centurion-Yah AR, Trujjillo-Aguirre J, Latournerie-Moreno L, Sauri-Duch E (2007). Characterization of total capsaicinoids, colour and volatile compounds of Habanero chilli pepper (Capsicum chinense Jack.) cultivars grown in Yucatan. Food Chemistry, 104: 1682-1686

30. Marin A, Ferreres F, Barberan FA, Gil MI (2004). Characterization and quantification of antioxidant constituents of sweet pepper (Capsicum annuum L.). Journal of Agricultural and Food Chemistry, 52: 3861-3868

31. Welsch R, Arango J, Bar C, Salazar B, Al-Babilis $\mathrm{S}$, Beltran J, Chavarriaga P, Ceballos H, Tohme J, Beyer P (2010). Provitamin A Accumulation in Cassava (Manihot esculenta) Roots Driven by a Single Nucleotide Polymorphism in a Phytoene Synthase Gene. Plant Cell, 22 (10): 3348-3356

32. Ha SH, Kim JB, Park JS, Lee SW, Cho KJ (2007). A comparison of the carotenoid accumulation in Capsicum varieties that show different ripening colours: deletion of the capsanthin-capsorubin synthase gene is not a prerequisite for the formation of a yellow pepper. Journal of Experimental Botany, 58:3135-3144

33. IOM (Institute of Medicine) (2006). Dietary Reference Intakes: The Essential Guide to Nutrient Requirements. États-Unis : National Academy Press

34. Frary A, Keçeli MA, Okmen B, Sigva HO, Yemenicioglu A, Doganlar S (2008). Watersoluble Antioxidant Potential of Turkish Pepper Cultivars. Hort science, 43 (3): 631-636

35. Guil-Guerrero JL, Martinez-Guirado C, M. Rebolloso-Fuentes M, Carrique-Perez (2006). Nutrient composition and antioxidant activity of 10 pepper (Capsicum annuum L.) varieties. European Food Rescharch Technology, 224: 1-9

36. Kumar OA, Tata SB (2009). Ascorbic Acid Contents in Chili Peppers (Capsicum L.). Notulae Scientia Biologicae, 1 (1): 50-52 